\title{
COLOR IMAGE RETRIEVAL BASED ON FUZZY NEURAL NETWORKS AND SWARM INTELLIGENCE TECHNIQUES
}

\author{
BAYDAA IBRAHEEM KHALEEL \\ Computer Science Department, College of Computer Science \& Mathematics, \\ University of Mosul, Mosul, Iraq \\ *Corresponding author: baydaaibraheem@uomosul.edu.iq
}

(Received: 21 $1^{\text {st }}$ January 2021; Accepted: $23^{\text {rd }}$ February 2021; Published on-line: $4^{\text {th }}$ January 2022)

\begin{abstract}
Image retrieval is an important system for retrieving similar images by searching and browsing in a large database. The image retrieval system can be a reliable tool for people to optimize the use of image accumulation, and finding efficient methods to retrieve images is very important. Recent decades have marked increased research interest in field image retrieval. To retrieve the images, an important set of features is used. In this work, a combination of methods was used to examine all the images and detect images in a database according to a query image. Linear Discriminant Analysis (LDA) was used for feature extraction of the images into the dataset. The images in the database were processed by extracting their important and robust features and storing them in the feature store. Likewise, the strong features were extracted for specific query images. By using some Meta Heuristic algorithms such as Cuckoo Search (CS), Ant Colony Optimization (ACO), and using an artificial neural network such as single-layer Perceptron Neural Network (PNN), similarity was evaluated. It also proposed a new two method by hybridized PNN and CS with fuzzy logic to produce a new method called Fuzzy Single Layer Perceptron Neural Network (FPNN), and Fuzzy Cuckoo Search to examine the similarity between features for query images and features for images in the database. The efficiency of the system methods was evaluated by calculating the precision recall value of the results. The proposed method of FCS outperformed other methods such as PNN, ACO, CS, and FPNN in terms of precision and image recall.
\end{abstract}

ABSTRAK: Imej dapatan semula adalah sistem penting bagi mendapatkan imej serupa melalui carian imej dan melayari pangkalan besar data. Sistem dapatan semula imej ini boleh dijadikan alat boleh percaya untuk orang mengoptimum penggunaan pengumpulan imej, dan kaedah pencarian yang berkesan bagi mendapatkan imej adalah sangat penting. Beberapa dekad yang lalu telah menunjukan banyak penyelidikan dalam bidang imej dapatan semula. Bagi mendapatkan imej-imej ini, ciri-ciri set penting telah digunakan. Kajian ini menggunakan beberapa kaedah bagi memeriksa semua imej dan mengesan imej dalam pangkalan data berdasarkan imej carian. Kami menggunakan Analisis Diskriminan Linear (LDA) bagi mengekstrak ciri imej ke dalam set data. Imej-imej dalam pangkalan data diproses dengan mengekstrak ciri-ciri penting dan berkesan daripadanya dan menyimpannya dalam simpanan ciri. Begitu juga, ciri-ciri penting ini diekstrak bagi imej carian tertentu. Persamaan dinilai melalui beberapa algoritma Meta Heuristik seperti Carian Cuckoo (CS), Pengoptimuman Koloni Semut (ACO), dan menggunakan lapisan tunggal rangkaian neural buatan seperti Rangkaian Neural Perseptron (PNN). Dua cadangan baru dengan kombinasi hibrid PNN dan CS bersama logik kabur bagi menghasilkan kaedah baru yang disebut Lapisan Tunggal Kabur Rangkaian Neural Perceptron (FPNN), dan Carian Cuckoo Kabur bagi mengkaji persamaan antara ciri carian imej dan imej pangkalan data. Nilai kecekapan kaedah sistem dinilai dengan mengira 
ketepatan mengingat pada dapatan hasil. Kaedah FCS yang dicadangkan ini mengatasi kaedah lain seperti (PNN), (ACO), (CS) dan (FPNN) dari segi ketepatan dan ingatan imej.

KEYWORDS:image retrieval; linear discriminant analysis (LDA); cuckoo search (CS); ant colony optimization (ACO); neural network

\section{INTRODUCTION}

We are witnessing an era of great development in the fields of information techniques, Internet, and services for web. People can take pictures anywhere, anytime, using mobile smart phones or digital cameras. This has led to a significant increase in the use of image groups and digital media. To obtain integrated and rapid capabilities of the current technology and to facilitate dealing with large image groups, there must be effective capabilities and rapid mechanisms for user-driven image searching through huge image datasets. Therefore, efficient and fast methods of retrieving images must be used. Here, some artificial intelligence techniques are used. Image retrieval methods are used in important areas such as security, criminal investigation, and medical imaging [1,2]. Feature extraction refers to the study of dimensionality reduction methods that describe the data. Its purpose is to reduce computational costs by using fewer features to represent data, without degrading discriminatory ability. Feature extraction is the process of using a subset of the original feature areas [3]. Artificial neural networks are a branch of artificial intelligence techniques that are computational structures that can be trained on to learn models from examples. Optimal solutions can be reached using the training group that tests the relationship between inputs and outputs and the method of learning, and networks that learn through supervision do local improvement [4]. Swarm intelligence is also one of the branches of artificial intelligence technology that depends on social behaviour. Its behaviour is inspired by nature, and the swarm has a great tolerance, so the failure of one factor does not stop the performance of the whole system. Swarm intelligence has enormous applications in many areas such as image processing, robotics, and telecommunications [5].

In this work, the linear discriminant analysis (LDA) algorithm was used for dimensionality reduction and to extract important features from the image datasets and query images. Meta Heuristic algorithms were used, such as algorithms of CS and ACO. Single layer perceptron neural network was also used and then the fuzzy membership function with single layer perceptron and CS were combined to produce a new method called fuzzy single layer perceptron neural network (FPNN). Fuzzy Cuckoo Search (FCS) found similar images and place them in one class, i.e. to create several classes of the input images group, each class contained similar images, and to find similarities between the query images and the group of images in the image database being used.

\section{PREVIOUS WORKS}

The use of ACO algorithm to retrieve images from 120 images with an accuracy of 91.6\% for the image retrieval system has been reported [1]. Ramandeep and Ashok used the Cuckoo Search Engine for content based image retrieval. They compared Cuckoo search to neural networks, which took more iterations [6]. Arvind et al.presented a feed-forward neural network to recall and retrieve images and, due to its highly efficient and accurate classification capability, they obtained a retrieval precision equal to $88 \%$ and recall rate equal to $78 \%$ [4]. Pathareand Kimmatkar[7]implemented a system that was a mixture of a color-feature based recovery, Firefly, and SVM for region-based image retrieval (RBIR). The accuracy result gained in the retrieval of the RBIR images equalled to $95 \%$ and TPR 
was equal to $65 \%$. Kurchaniya and Johari[8] extracted edge and texture information of images using IEHD and RLBP respectively, and they used PSO to measure similarities between images. All images in the databases used gave a better result in terms of accuracy and recall, where the system was implemented on three types of database. They reached accuracy rates equal to $84.60 \%$ for LI database, $85.62 \%$ for WANG, and $85.20 \%$ for Caltech-101databases. Nie proposed a network model based on the particle swarm optimization algorithm and then established a mathematical model based on swarm intelligence for a Use Content-based image retrieval [9].

\section{LINEAR DISCRIMINANT ANALYSIS (LDA)}

The goal of the Linear Discriminant Analysis technique is to project the original data matrix onto a lower dimensional space. The LDA method has been developed in order to transform features into space with fewer dimensions, and this increases the variance between classes and reduces the variance within the class. This helps to obtain the highest separation between classes. Consider a group of $N$ image samples $\left\{x_{1}, x_{2}, \ldots \ldots x_{n}\right\}$, where image space takes upn-dimensional. Assume $C_{\text {classes }}\left\{C_{1}, C_{2}, \ldots \ldots C_{c}\right\}$ and each image belongs to one of these classes. There are $N i$ samples in a class. Then,

$$
C_{i}(i=1,2,3, \ldots ., c), \mu_{i}=1 / N \sum_{i=1}^{N} x_{i}
$$

is the mean of the samples in class $C_{i}$, and the between-class scatter matrix $S_{B}$ is defined as

$$
S_{B}=\frac{1}{N} \sum_{i=1}^{c} N_{i}\left(\mu_{i}-\mu\right)\left(\mu_{i}-\mu\right)^{T}
$$

The within-class matrix $S_{w i s}$ defined as

$$
\begin{aligned}
& S_{\omega}=\frac{1}{N} \sum_{i=1}^{c} \sum_{x_{k} \in c_{i}}\left(x_{i}-\mu_{i}\right)\left(x_{i}-\mu_{i}\right)^{T} \\
& W_{o p}=\arg m \times w\left|\frac{W^{T} S_{B} W}{W^{T} S_{\omega} W}\right|=\left[\omega_{1} \omega_{2} \omega_{3} \omega_{4} \ldots \ldots \ldots \ldots \omega_{j}\right]
\end{aligned}
$$

where $\left\{W_{i} \mid i=1,2,3, \ldots \ldots j\right\}$ denote generalized eigenvector sets $S_{B}$ and $S_{w}$ that correspond to $(m)$ largest generalized Eigen values $\left\{\lambda_{i}=1,2,3, \ldots \ldots j\right\}$ or their mean $[3,10]$.

$$
S_{B} \omega_{i}=\lambda_{i} S_{\omega} \omega_{i}, i=1,2,3, \ldots, j
$$

\section{ANT COLONY OPTIMIZATION}

Meta-heuristic algorithms based on the principles of artificial intelligence are most used in image processing, in the fields of engineering and informatics [5,11]. An ant colony's algorithm is a meta-heuristic algorithm that belongs to the intelligence of swarms and is based on the behavior of ants. Ants, by their nature, are able to find the shortest path from the source of the food to the nest. To do this, the ant places a chemical on the ground as a guide for others to find food. The path selection for later ants depends on the density of the chemical, and therefore the behaviour of the ants stimulates the emergence of an algorithm consisting of a group of intelligent ants (artificial ants) as a group of simple agents that work with each other to solve problems by exchanging information via chemicals (pheromones) that act as a distributed memory to the linked ants. Therefore, this algorithm representing system ants is applied to a number of complex optimization problems. From the ants' foraging behaviour, the idea of the algorithm came about as follows [12]: 
A group of ants begin to leave the cell randomly in multiple directions. This process occurs the first time only, but subsequently the ants choose a specific path after testing each path.

- An ant secretes a certain percentage of pheromone as it passes and that pheromone is used to know the path the ant has passed.

- When finding the food source, the ant takes a sufficient amount of it, then returns to the cell, and chooses a specific path where it chooses the path that has the largest amount of pheromone. When the ant returns, the same amount of pheromone is released.

- When the ant leaves the cell again, it tests the amount of pheromone in all paths and chooses the path with the largest amount of pheromone.

- In each determined time period, the pheromone amount is updated, because the pheromone concentration will disappear over time.

It has been observed that the shortest path is always the one that contains the largest pheromone amount. Therefore, this is the path through which all ants will pass. The ant algorithm is a dynamic algorithm, meaning that if a problem occurs in the shorter path, a new path ant will choose in same way. The steps of the Ant Colony Optimization algorithm are $[12,13]$ :

1.Ant Searching Behavior as follows:

When the ant $K$ is in celli, it uses the heuristic function $\eta_{i j}$, and pheromone $\tau_{i j}$ to calculate the probability that it will choose cell $j$ as the next cell according of the following equation:

$$
P_{i j}^{K}= \begin{cases}\frac{\tau_{i j}^{\alpha} \cdot \eta_{i j}^{\beta}}{\sum_{\left.j \in N_{i}^{(K)}\right)_{i j}^{\alpha} \cdot \eta_{i j}^{\beta}}} & \text { if } j \in N_{i}^{K} \\ 0 & \text { otherwise }\end{cases}
$$

$N_{i}{ }^{(K)}$ represents the group of elements that do not belong to the partial solution of the ant. $K$, $\alpha$, $\beta$ represent fixed values that determine the importance of the pheromone substance and the heuristic information respectively, the heuristic function is calculated by the equation

$$
\eta_{i j}=\frac{1}{d_{i j}}
$$

and $d_{i j}$ represents the distance between the edge $i$ and the edgej.

2. Track the path and update the pheromone before returning to the parent node (nest), $K$, an ant places $\Delta \tau^{(K)}$ from a pheromone (the aromatic substance) on the edges it visited, so the value of the pheromone $\tau_{i j}$ at the edge $(i, j)$ that the ant has crossed is calculated as follows

$$
\tau_{i j}=\tau_{i j}+\Delta \tau^{(K)}
$$

In general, the increase in the amount of pheromone on a specific edge leads to an increase in the probability of being selected by the rest of the ants in the colony.

3. Pheromone Trail Evaporation. The pheromone begins to evaporate from all edges when $K$ ant moves to next node, as shown in following equation

$$
\tau_{i j}=(1-p)_{\tau_{i j}}
$$




$$
\forall(i, j) \in A
$$

As the $p \in(0,1)$ represent the coefficient of evaporation, Aindicates the edges that an ant traversed on its way from the parent node to the destination, and generally the evaporation of the pheromone contributes to increasing the ability of the algorithm to explore different paths during the search process, and also contributes to reducing the amount of pheromone on the edges.

To update the pheromone after ants return to the main node, according to following equation

$$
\tau_{i j}=(1-p)_{\tau_{i j}}+\sum_{K=1}^{N} \Delta \tau_{i j}^{K}
$$

The goal of updating the pheromone is to increase the pheromone amount associated with promising and good paths. Therefore, the pheromones placed at the edge by the $K$ ant are calculated as shown in the equation:

$$
\Delta \tau_{i j}^{K}=\frac{R}{L_{K}}
$$

As $R$ represents a fixed value that works to determine the amount of increase in the amount of pheromone in a limited range, $L$ represents the path that the ant $K$ crosses and in general the repetition represents a complete cycle that includes the movement of ants and the evaporation of the pheromone.

In this paper, the clustering process was adopted using the Mahalanobis distance to find the similarity between the query image and the database images by calculating the distance according to the following equation:

$$
\text { dist }_{i j}=\left(\text { data }_{j}-\text { center }_{i}\right)^{T} A_{i}\left(\text { data }_{j}-\text { center }_{i}\right)
$$

where this algorithm gave satisfactory results in the process of retrieving colour images.

\section{SINGLE LAYER PERCEPTRON NEURAL NETWORK}

Single layer perceptron SLP consist of input layer and output layer. Each layer consists of one or more neurons (nodes), and each node in the input layer receives information from the outside world and is linked by connection weights with all nodes in the output layer. The data flows from the input layer to the output layer, and in the event of an error during learning, weights are changed. Perceptron neural network is used for resolving linearly separable data. The steps of basic perceptron algorithm as follows [4]:

Firstly, initialize weights at random $W_{k j}$, and for each training pair / pattern $\left[X_{i}, t_{i}\right]$, where $X_{i}=x_{1}, x_{2}, \ldots \ldots x_{n}$, then compute output $Y$, and compute error

$$
E_{i}=t_{i}-\mathrm{f}\left(\sum_{\mathrm{k}} \mathrm{W}_{\mathrm{ik}} \mathrm{X}_{\mathrm{k}}\right)=t_{i}-f\left(\text { net }_{i}\right)
$$

And finally use the error to update weights as follows

$$
W_{i j}^{\text {new }}=W_{i j}^{\text {old }}+\Delta W_{i j}
$$

where $\Delta W_{i j}=\alpha * \mathrm{e}_{\mathrm{i}} * \mathrm{E}_{\mathrm{i}}$ 
cis the learning rate, and it is a small value that is greater than zero. Repeat the step until convergence [4,14].

In this paper, to improve the work of the perceptron network and accelerate the access to the optimal solution, the neural network was hybridized with fuzzy logic by adding a membership function to the equation of adjusting the weights to ensure that the ideal weights are obtained with the least time and effort. Here, a new proposed method was obtained that called it Fuzzy Single Layer Perceptron Neural Network (FPNN) as shown in equations below:

$$
\begin{aligned}
& \Delta W_{i j}=U_{i}(t) \alpha * \mathrm{e}_{\mathrm{i}}^{*} \mathrm{E}_{\mathrm{i}} \\
& U_{i}=\left(\mu_{i k}\right)^{f_{m}} \\
& \mu_{i k}=\frac{\left(\frac{1}{D_{i k}}\right)^{\frac{1}{f_{m}-1}}}{\sum_{p=1}^{c}\left(\frac{1}{D_{p k}}\right)^{\frac{1}{f_{m}-1}}}
\end{aligned}
$$

where $U_{i}$ denotes the fuzzy membership function, and $D_{i k}=d\left(x_{k}, w_{i}\right)$ represents the Euclidean distance between the input data and the weights of the output cells that play an important role in computing the value of the membership function.

\section{CUCKOO SEARCH}

This algorithm is based on behaviour inspired from nature. A cuckoo will lay its eggs in other birds' nests so that the other birds will raise their cuckoo babies. If the other bird discovers that an egg in its nest is not its own, the unwanted and unfamiliar egg would be pushed and rejected from the nest. The cuckoo algorithm uses this principle to model a new solution as a cuckoo egg where every egg in a nest represents a unique solution. A bad solution can be replaced by a new solution in the nest. There are basic rules used in the cuckoo algorithm:

- Only one egg is placed by the cuckoo at a time, where the cuckoo randomly selects a nest and places the egg in it

- Desired nests with lots of eggs will be passed on to the next generation

- The nest of the host will be repaired. The host bird detects an egg that the cuckoo bird lays with probability $\mathrm{p}_{\mathrm{d}}$. In such a case, this egg will either be thrown out by the host bird or it will build a new nest elsewhere.

According to these basic rules, basic CS algorithm steps can be explained at follows:

Start

Objective Function $\quad f(y)=\left(y_{1}, y_{2}, \ldots \ldots \ldots, y_{s}\right)^{T}$

Initialize a Random population of $n$ host nest $y_{i}$

While $(t<$ MaxGen)

Get randomly a cuckoo (example $i$ ) by Lévy Flights

Fitness function Evaluation $f_{i}$

Choose randomly a nest from $n$ (example $j$ ) with Fitness $f_{j}$

If $\left(f_{j} \geq f_{i}\right)$

Replace $j$ with new solution;

End 


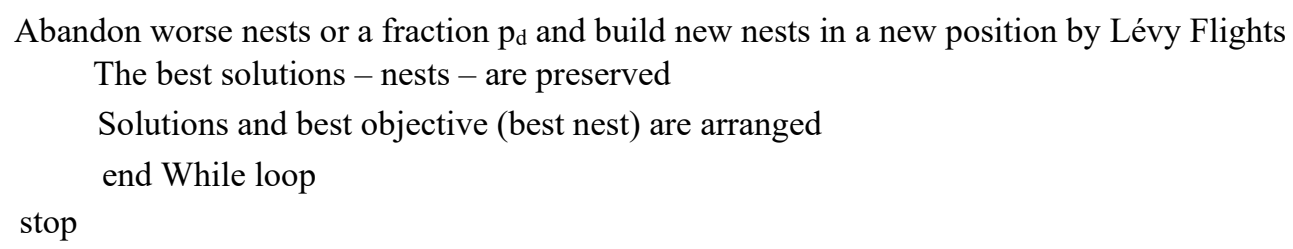

New solutions $y^{(i+1)}$ for cuckoos $i$, when found, implement Lévy flight using the following equation

$$
y_{i}^{(t+1)}=y_{i}^{t}+\alpha \oplus L e^{\prime} v y(\lambda)
$$

where $\alpha>0$ represent step size, we can take $\alpha$ as 1 . $\oplus$ denotes of the entry wise multiplications. Whereas, Lévy flights mainly provide random walk, while from the Lévy distribution, its random steps are drawn into large steps, as in equation below.

$$
L e^{\prime} v y \sim u=t^{-\lambda} .(1<\lambda \leq 3)
$$

Lévy flight provides random walking and forms random walking with step length distribution. On the current best solution, new solutions are created which help speed up local search $[15,16]$.

In this method, the clustering principle was used in the retrieval process by using the Mahalanobis distance to find the distance between the features of the database images and the query image to calculate the similarity value between these images, and retrieve the images related to the query image with high accuracy by employing this distance within the cuckoo algorithm in the calculation of the fitness function to obtain the optimal solution, high accuracy of retrieval, and excellent results, as shown in the tables.

When developing this algorithm by adding the fuzzy membership function to the fitness function, a proposed method was obtained, called fuzzy cuckoo search algorithm (FCS), which obtained better results.

\section{DESIGN OF PROPOSED SYSTEM}

The system is designed to retrieve images based on some artificial intelligence techniques such as the swarm algorithms, which are represented by the Ant Colony (ACO) algorithm and the Cuckoo Search (CS) algorithm. Additionally, artificial neural networks were used such as the perceptron neural network (PNN) and the proposed methods of Fuzzy Perceptron Neural Network (FPNN) and Fuzzy Cuckoo Search (FCS) that were used to retrieve the images, as shown in Fig. 1.

These methods (PNN, ACO, CS, FPNN, and FCS) have been built to retrieve images from the datasets. In the training phase, these five methods are able to retrieve accurate and similar images with high efficiency on their own. The image retrieval system based on these five methods was designed to include two stages: the training phase and the testing phase. Initially, we used the Linear Discriminant Analysis (LDA) to extract features for all the images in the database as well as the query image. In the training phase, the features extracted from the images are entered to the ACO, CS, PNN, FPNN, and FCS in order to learn these methods, and the base knowledge is stored in these five methods through the training process. This knowledge is used in the testing phase for comparison and decision making by these methods (PNN, ACO, CS, FPNN, and FCS). The comparison involves comparing features between query images and the trained image set, where the best images with identical and similar features are retrieved. 


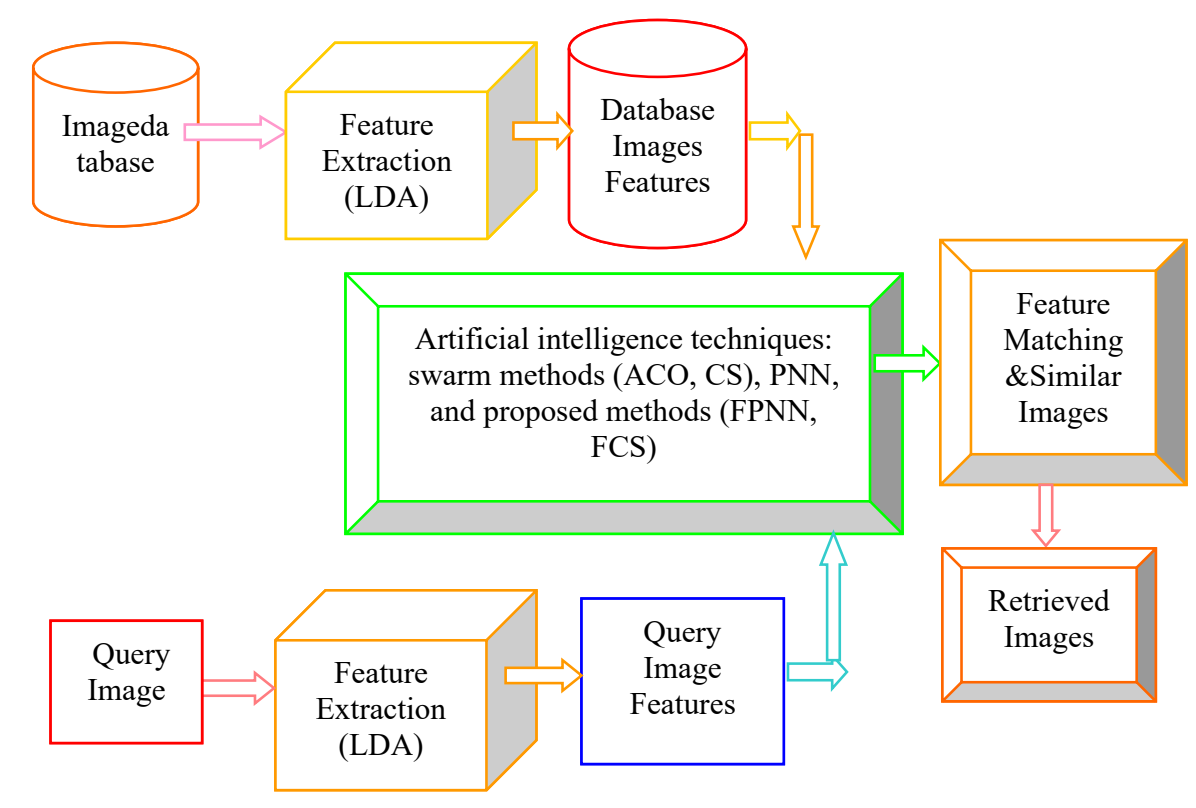

Fig. 1: System flowchart of the image retrieval.

\section{EXPERIMENTAL RESULTS}

In this paper, five artificial intelligent methods were used: Cuckoo Search (CS), Ant Colony optimization (ACO), and then combined Fuzzy membership function with SLP neural network and CS to produce Fuzzy single layer perceptron neural network (FPNN), and Fuzzy Cuckoo search (FCS). Linear Discriminant Analysis (LDA) was also used for feature extraction of the image database and Query image. To evaluate the performance of these methods, we used two indicators, recall and precision [17], as shown in Eq. (21), Eq. (22):

$$
\begin{aligned}
& \text { Re } \text { call }=\frac{\text { No. of relevant images retrieved }}{\text { Total no. of relevant image in the collection }} \times 100 \\
& \text { Pr ecision }=\frac{\text { No. of relevant images retrieved }}{\text { Total no. of images retrieved }} \times 100
\end{aligned}
$$

In this work we used an image dataset that contained 10 categories, each category contained different numbers of images. The image categories are shown in Table 1. The five methods PNN, ACO, CS, FPNN, and FCS were applied to this database. In the training phase, these methods obtained 10 cluster centres, according to ten image categories, these methods discovered all the data in the database completely and accurately. In the testing phase, query images for each category were entered on these methods (PNN, ACO, CS, FPNN, FCS). The distance between query image features and cluster centres for 10 categories, minus the distance equates to the similarity. These methods find the similarity and matching between the query image and the images in the stored database.

Table 1: Images dataset

\begin{tabular}{ccc}
\hline Category type & Number of images & Rate\% \\
\hline california_Gull & 61 & 17.23 \\
mflowers & 44 & 12.43 \\
cflowers & 15 & 4.24
\end{tabular}




\begin{tabular}{ccc} 
rose_marron & 18 & 5.08 \\
nflower & 15 & 4.24 \\
blue_winged_warble & 59 & 16.67 \\
brown_pelican & 56 & 15.82 \\
cardinal & 57 & 16.10 \\
horse & 10 & 2.82 \\
human & 19 & 5.37 \\
total & 354 & $100 \%$ \\
\hline
\end{tabular}

The recall rate and precision rate were calculated for all these methods. Different (Recall and Precision) rates were obtained for (PNN, ACO, CS) and FPNN methods (Table 2 ). While the FCS method obtained Recall rate and Precision rate equal (100\%), the FCS is better than (PNN, ACO, CS) and FPNN methods. Table 3 shows the results for all methods PNN, ACO, CS, FPNN and FCS that were used in this work. This table contains query image, category type, relevant retrieved, retrieved number, recall rate, and precision rating for these methods.

From these tables, we note that the FCS method was the best as the values of recall and precision were equal to $100 \%$, while the values of recall and precision for FPNN were equal to 97.2 and 87.83 respectively.

We notice that the order of preference of the methods was as follows: first the PNN method gave results that are not good, then the ACO method had better results, and when using the CS method, the results became better than the previous two methods. Then the PNN method was developed by hybridizing it with fuzzy logic, where very satisfactory results were obtained. From monitoring the results of the CS method, the precision values were equal to $100 \%$ and that by the FPNN hybrid method and the recall values were high compared to other methods. Therefore, the CS method was hybridized with fuzzy logic to improve its performance. The best results were obtained with this proposed method of fuzzy hybridization, where the values of recall and precision were equal to $100 \%$. Figure 2 shows the samples of query images for all categories of database. Figures 3-7 show the number of relevant - retrieved images for all methods used in this work.

Table 2: Recall rate and precision rate for PNN, ACO, CS and FPNN methods

\begin{tabular}{ccccccccc}
\hline \multirow{2}{*}{ Category type } & \multicolumn{2}{c}{ PNN } & \multicolumn{2}{c}{ ACO } & \multicolumn{2}{c}{ CS } & \multicolumn{2}{c}{ FPNN } \\
\cline { 2 - 9 } & $\begin{array}{c}\text { Recall } \\
\text { rate\% }\end{array}$ & $\begin{array}{c}\text { Precision } \\
\text { rate\% }\end{array}$ & $\begin{array}{c}\text { Recall } \\
\text { rate\% }\end{array}$ & $\begin{array}{c}\text { Precision } \\
\text { rate\% }\end{array}$ & $\begin{array}{c}\text { Recall } \\
\text { rate\% }\end{array}$ & $\begin{array}{c}\text { Precision } \\
\text { rate\% }\end{array}$ & $\begin{array}{c}\text { Recall } \\
\text { rate\% }\end{array}$ & $\begin{array}{c}\text { Precision } \\
\text { rate\% }\end{array}$ \\
\hline california_Gull & 81.967 & 69.4 & 95.08 & 90.63 & 96.72 & 100 & 98.36 & 98.36 \\
mflowers & 68.18 & 53.57 & 86.36 & 79.16 & 95.45 & 100 & 97.72 & 100 \\
cflowers & 60 & 39.13 & 73.3 & 78.57 & 93.3 & 100 & 93.33 & 87.5 \\
rose_marron & 72.2 & 38.24 & 83.3 & 93.75 & 88.8 & 100 & 94.44 & 100 \\
nflower & 66.7 & 55.6 & 73.3 & 91.7 & 86.7 & 100 & 93.33 & 93.33 \\
Blue_winged_warble & 61.02 & 56.3 & 83.1 & 92.45 & 91.53 & 100 & 96.61 & 100 \\
brown_pelican & 85.71 & 64.86 & 91.07 & 80.95 & 94.64 & 100 & 98.21 & 98.21 \\
cardinal & 82.46 & 68.12 & 92.98 & 89.83 & 96.49 & 100 & 100 & 100 \\
horse & 80 & 30.77 & 80 & 57.14 & 90 & 100 & 100 & 90.90 \\
human & 57.89 & 30.6 & 73.68 & 60.87 & 94.74 & 100 & 100 & 100 \\
Average & 71.6127 & 50.659 & 83.217 & 81.505 & 92.837 & 100 & 97.2 & 87.83 \\
\hline
\end{tabular}

Table 3: The results for PNN, ACO, CS, FPNN and FCS methods with query images, category type, relevant retrieved, retrieved number, recall rate, and precision rate

\begin{tabular}{ccccccc}
\hline $\begin{array}{c}\text { Query } \\
\text { image }\end{array}$ & $\begin{array}{c}\text { Category } \\
\text { type }\end{array}$ & $\begin{array}{c}\text { Relevant } \\
\text { retrieved }\end{array}$ & $\begin{array}{c}\text { Retrieved } \\
\text { number }\end{array}$ & Recall rate & $\begin{array}{c}\text { Precision } \\
\text { rate }\end{array}$ & Method \\
\hline
\end{tabular}




\begin{tabular}{|c|c|c|c|c|c|c|}
\hline & \multirow{5}{*}{ california_Gull } & 50 & 72 & 81.967 & 69.4 & PNN \\
\hline & & 58 & 64 & 95.08 & 90.63 & $\mathrm{ACO}$ \\
\hline & & 59 & 59 & 96.72 & 100 & $\mathrm{CS}$ \\
\hline & & 60 & 61 & 98.36 & 98.36 & FPNN \\
\hline & & 61 & 61 & 100 & 100 & FCS \\
\hline \multirow[b]{5}{*}{ the } & \multirow{5}{*}{ Mflowers } & 30 & 56 & 68.18 & 53.57 & PNN \\
\hline & & 38 & 48 & 86.36 & 79.16 & $\mathrm{ACO}$ \\
\hline & & 42 & 42 & 95.45 & 100 & $\mathrm{CS}$ \\
\hline & & 43 & 43 & 97.72 & 100 & FPNN \\
\hline & & 44 & 44 & 100 & 100 & FCS \\
\hline \multirow{5}{*}{ tranda } & \multirow{5}{*}{ Cflowers } & 9 & 23 & 60 & 39.13 & PNN \\
\hline & & 11 & 14 & 73.3 & 78.57 & $\mathrm{ACO}$ \\
\hline & & 14 & 14 & 93.3 & 100 & $\mathrm{CS}$ \\
\hline & & 14 & 16 & 93.33 & 87.5 & FPNN \\
\hline & & 15 & 15 & 100 & 100 & FCS \\
\hline \multirow{6}{*}{ senter } & \multirow{5}{*}{ rose_marron } & 13 & 34 & 72.2 & 38.24 & PNN \\
\hline & & 15 & 16 & 83.3 & 93.75 & $\mathrm{ACO}$ \\
\hline & & 16 & 16 & 88.8 & 100 & CS \\
\hline & & 17 & 17 & 94.44 & 100 & FPNN \\
\hline & & 18 & 18 & 100 & 100 & FCS \\
\hline & \multirow{5}{*}{ Nflower } & 10 & 18 & 66.7 & 55.6 & PNN \\
\hline \multirow{4}{*}{ nestas } & & 11 & 12 & 73.3 & 91.7 & $\mathrm{ACO}$ \\
\hline & & 13 & 13 & 86.7 & 100 & CS \\
\hline & & 14 & 15 & 93.33 & 93.33 & FPNN \\
\hline & & 15 & 15 & 100 & 100 & FCS \\
\hline & \multirow{5}{*}{$\begin{array}{c}\text { blue_winged_ } \\
\text { warble }\end{array}$} & 36 & 64 & 61.02 & 56.3 & PNN \\
\hline & & 49 & 53 & 83.1 & 92.45 & $\mathrm{ACO}$ \\
\hline & & 54 & 54 & 91.53 & 100 & $\mathrm{CS}$ \\
\hline & & 57 & 57 & 96.61 & 100 & FPNN \\
\hline & & 59 & 59 & 100 & 100 & FCS \\
\hline & \multirow{5}{*}{ brown_pelican } & 48 & 74 & 85.71 & 64.86 & PNN \\
\hline & & 51 & 63 & 91.07 & 80.95 & $\mathrm{ACO}$ \\
\hline & & 53 & 53 & 94.64 & 100 & $\mathrm{CS}$ \\
\hline & & 55 & 56 & 98.21 & 98.21 & FPNN \\
\hline & & 56 & 56 & 100 & 100 & FCS \\
\hline & \multirow{5}{*}{ Cardinal } & 47 & 69 & 82.46 & 68.12 & PNN \\
\hline & & 53 & 59 & 92.98 & 89.83 & $\mathrm{ACO}$ \\
\hline & & 55 & 55 & 96.49 & 100 & $\mathrm{CS}$ \\
\hline & & 57 & 57 & 100 & 100 & FPNN \\
\hline & & 57 & 57 & 100 & 100 & FCS \\
\hline \multirow{5}{*}{$-4)^{2}$} & \multirow{5}{*}{ Horse } & 8 & 26 & 80 & 30.77 & PNN \\
\hline & & 8 & 14 & 80 & 57.14 & $\mathrm{ACO}$ \\
\hline & & 9 & 9 & 90 & 100 & $\mathrm{CS}$ \\
\hline & & 10 & 11 & 100 & 90.90 & FPNN \\
\hline & & 10 & 10 & 100 & 100 & FCS \\
\hline \multirow{5}{*}{$=1$} & \multirow{5}{*}{ Human } & 11 & 36 & $\begin{array}{l}57.89 \\
\end{array}$ & 30.6 & PNN \\
\hline & & 14 & 23 & 73.68 & 60.87 & $\mathrm{ACO}$ \\
\hline & & 18 & 18 & 94.74 & 100 & $\mathrm{CS}$ \\
\hline & & 19 & 19 & 100 & 100 & FPNN \\
\hline & & 19 & 19 & 100 & 100 & FCS \\
\hline
\end{tabular}




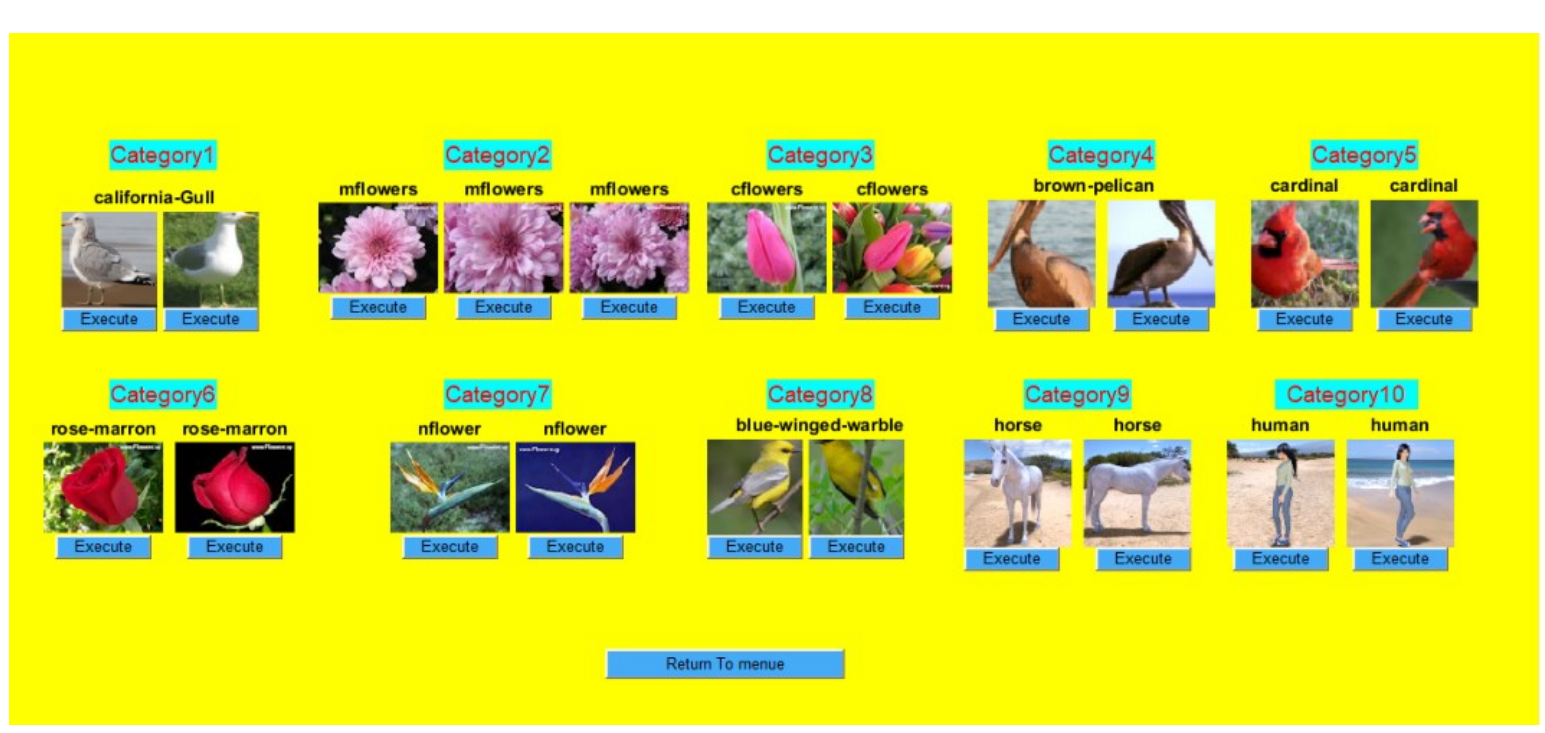

Fig.2:Query images for ten categories of image database.

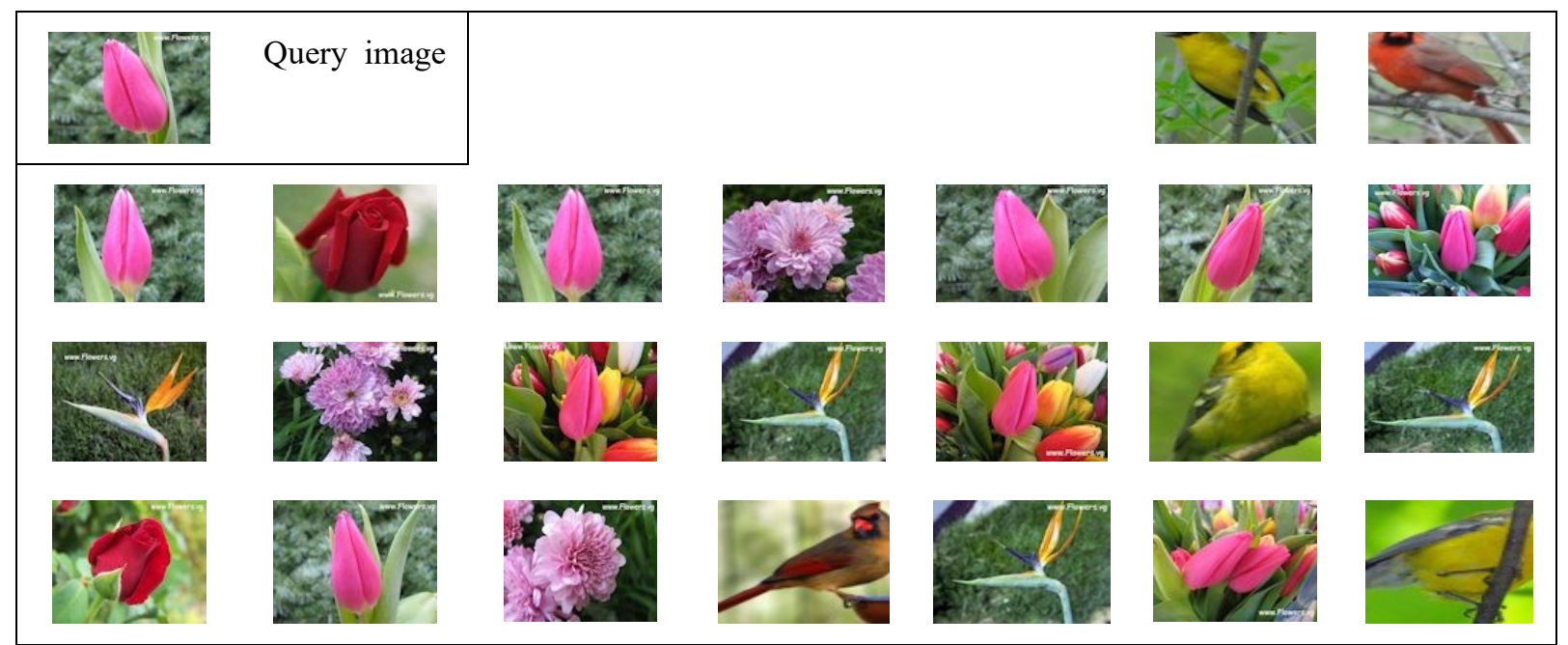

Fig. 3: Number of relevant-retrieved images $=9$ for $\mathrm{PNN}$ method.

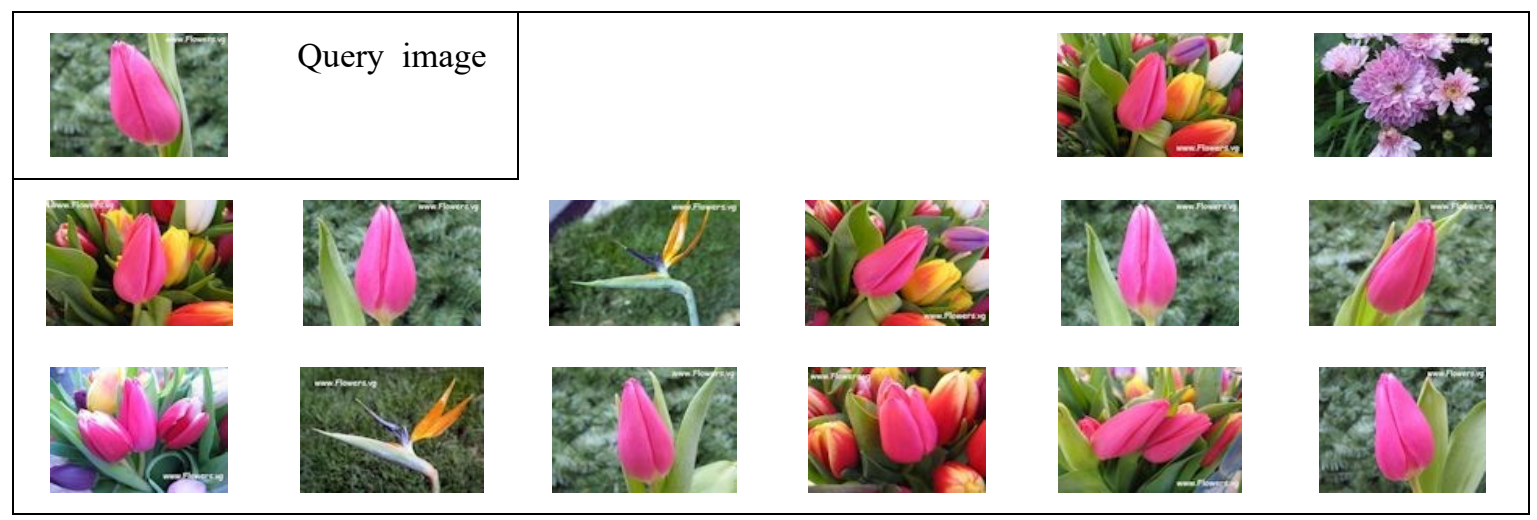

Fig. 4: Number of relevant-retrieved images $=11$ for ACO method. 


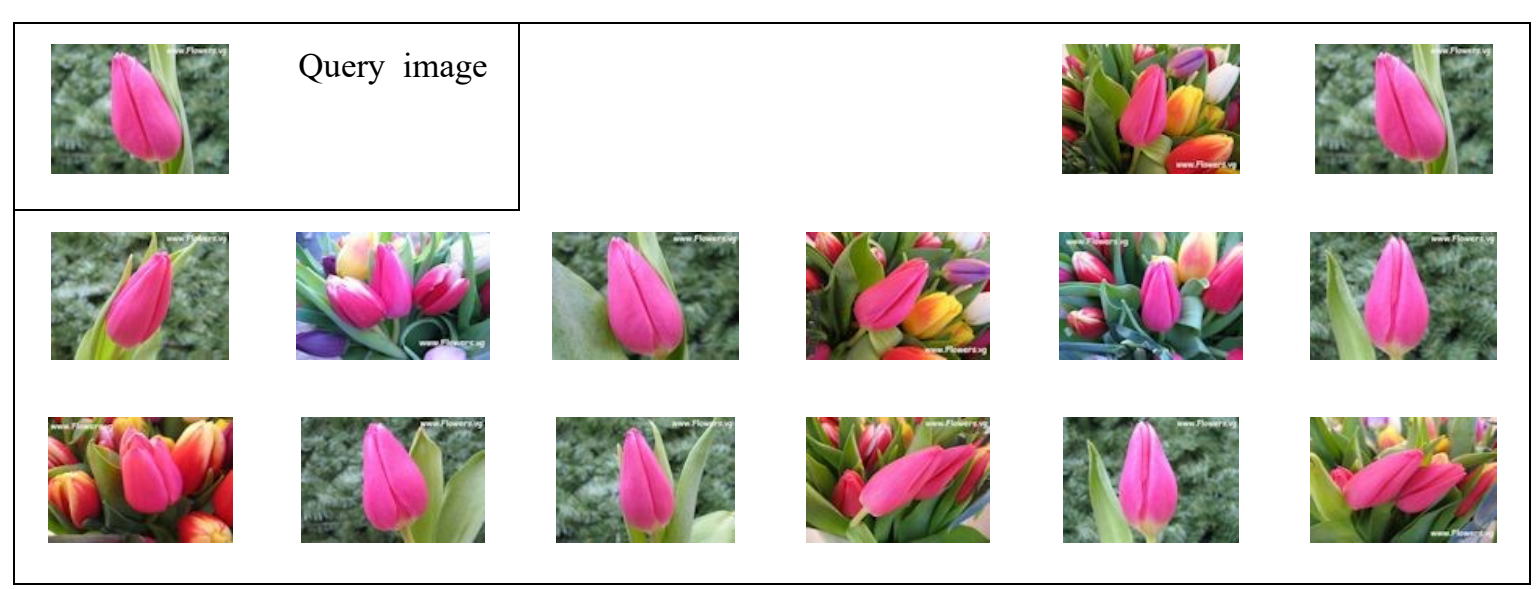

Fig. 5: Number of relevant-retrieved images $=14$ for CS method.

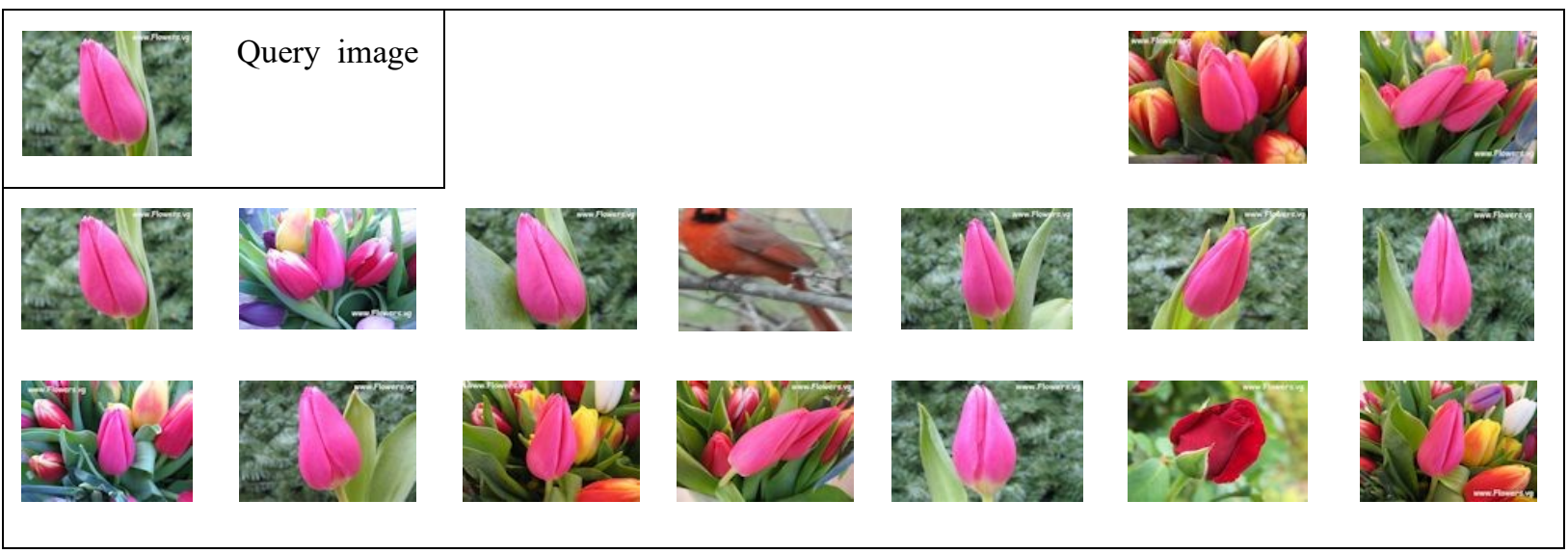

Fig.6: Number of relevant-retrieved images $=14$ for FPNN method.

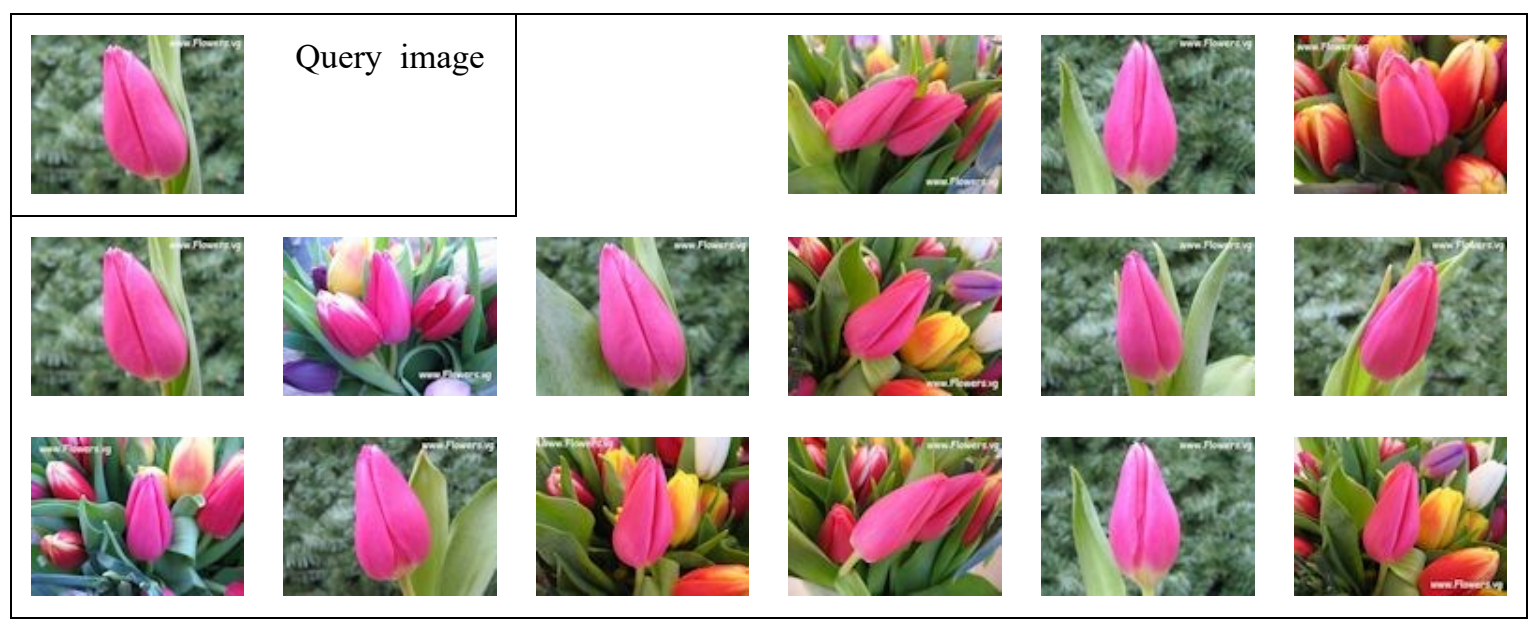

Fig. 7: Number of relevant-retrieved images $=15$ for FCS method.

\section{CONCLUSION}

In this paper, we used some of artificial intelligence techniques for image retrieval. Initially, we presented Linear Discriminant Analysis (LDA) for feature extraction of images in the dataset. Then we used some swarm algorithms such as ACO and CS optimization algorithms. We also used artificial neural network such as PNN, and combined the fuzzy membership function with single layer perceptron and Cuckoo search to produce new 
methods called Fuzzy Perceptron Neural Network (FPNN) and Fuzzy Cuckoo Search (FCS). These five methods were applied to an image dataset. We used two measures (recall and precision rate) for evaluating these methods. The FCS method got the best performance for image retrieval among the other methods (PNN, ACO, CS) and FPNN used in this work.

\section{ACKNOWLEDGMENT}

I offer my gratitude and thanks to the University of Mosul in Iraq, for providing the facilities to carry out this research.

\section{REFERENCES}

[1] Tessy AV. (2010) Performance enhanced optimization based image retrieval system. IJCA Special Issue on Evolutionary Computation, 1: 31-34.

[2] Hung HT, Bae MC, Shin HL. (2014) Rotation-invariant texture image retrieval using particle swarm optimization and support vector regression. Applied Soft Computing, 17: 127-139.

[3] Santhi N, Annbuselvi K, Sivakumar S. (2018) Performance analysis of feature extraction techniques: PCA and LDA for face recognition. Int JEngRes CompSciand Eng, 5(3): 289-294.

[4] Arvind N, Manimozhi, Jetendranath M. (2014) Content-based image retrieval system using feed-forward backpropagation neural network.Int J Comp Sci Network Security, 14(6): 70-77.

[5] Shahbaa IK, Karam MMS. (2012) Detection of network anomaly based on hybrid intelligence techniques. AL-Rafidain J Comp Sciences and Mathematics, 9(2): 81-98.

[6] Ramandeep K, Ashok KB. (2014) Enhanced content-based image retrieval using Cuckoo search algorithm. Int J Advanced Res Comp Sci Software Engineering, 4(9): 233-241.

[7] Pathare RN, Kimmatkar KW. (2016) Multi-step approach for speeding-up region based image retrieval using indexing technique. Int Res J Engineering and Technology, 3(8): 323- 327.

[8] Kurchaniya D, Johari PK. (2017) An efficient approach for image retrieval using particle swarm optimization. Int J Computer Sciences and Engineering, 5(6): 90-99.

[9] Nie Q. (2018) Research on image network retrieval application based on swarm optimization algorithm.Advances in Intelligent Systems Research, 147: 524-529.

[10] Steven F, JoseminB. (2013) Performance analysis of PCA-based and LDA based algorithms for face recognition. Int J Signal Processing Systems, 1(1): 1-6.

[11] Shahbaa IK, Ragad WK. (2014) Selection and prioritization of test cases by using bees colony. AL-Rafidain JComputer Sciences and Mathematics, 11(1): 179-201.

[12] Hasancebi O, Carba S. (2011) Ant colony search method in practical structural optimization. Int J Optimization in Civil Engineering, 1: 91-105.

[13] FangyuC,HongweiW, ChaoQ, YongX. (2013) An ant colony optimization routing algorithm for two order pickers with congestion consideration. Computers \& Industrial Engineering, 66: 77-85.

[14] Arvind N, Manimozhi I. (2013) Content-based image retrieval system using feed-forward backpropagation neural network. Int J Computer Science Engineering, 2(4): 143-151.

[15] Vennilal S, Venkatesan A. (2017) Improved color satellite image segmentation using cuckoo search algorithm.Int J Innovative Res Comp and Comm Eng, 5(4): 8229-8236.

[16] Priya V. (2018) Ant colony and Cuckoo search algorithm for document clustering. ARPN JEng Appl Sci, 13(7): 2429-2437.

[17] Yogapriya J, Saravanabhavan C, IlaV. (2017) An effective machine learning algorithm for texture based medical image retrieval system. Int Res J Pharmacy, 8(11): 201-218. 